\title{
Cross-amplification of nuclear microsatellite markers in two species of Cryptanthus Otto \& A. Dietr. (Bromeliaceae)
}

\author{
Débora Maria Cavalcanti Ferreira ${ }^{1} \cdot$ Jordana Neri $^{2} \cdot$ Clarisse Palma-Silva $^{3}$. \\ Diego Sotero Pinangé ${ }^{4} \cdot$ Ana Maria Benko-Iseppon ${ }^{5} \cdot$ Rafael Batista Louzada $^{4}$
}

Received: 1 June 2016/Accepted: 16 January 2017/Published online: 27 January 2017

(C) Botanical Society of Sao Paulo 2017

\begin{abstract}
Thirty-eight nuclear microsatellite loci originally developed for Aechmea caudata Lindm., Orthophytum ophiuroides Louzada \& Wand., Pitcairnia albiflos Herb., Vriesea gigantea (Gaud.) and V. simplex (Vell.) Beer were tested in Cryptanthus burle-marxii Leme and $C$. zonatus (Vis.) Vis. Of the 38 loci tested, 13 were polymorphic. Ten polymorphic microsatellite loci were selected to be amplified and genotyped in one population each of $C$. burle-marxii and $C$. zonatus. The observed and expected heterozygosity per locus in the C. burle-marxii population ranged from 0.050 to 0.850 and 0.050 to 0.770 , respectively. In $C$. zonatus, the observed and expected heterozygosity per locus ranged from 0.167 to 0.846 and 0.290 to 0.692 , respectively. The $O$. ophiuroides locus Op52 for the C. zonatus population and P. albiflos locus $\mathrm{PaC} 05$ for the two species showed significant departure from HWE. These ten polymorphic loci tested will be used to assess the genetic diversity and structure of the two species of Cryptanthus.
\end{abstract}

Débora Maria Cavalcanti Ferreira

deboracavalcantif@hotmail.com

1 Programa de Pós-Graduação em Biologia Vegetal, Universidade Federal de Pernambuco, Recife, PE 50670-901, Brazil

2 Programa de Pós-graduação em Botânica, Museu Nacional, Universidade Federal do Rio de Janeiro, Rio de Janeiro, RJ 20940-040, Brazil

3 Programa de Pós-Graduação em Ecologia e Biodiversidade, Universidade Estadual Paulista Júlio de Mesquita Filho, Rio Claro, SP 13506-900, Brazil

4 Departamento de Botânica, Universidade Federal de Pernambuco, Recife, PE 50670-901, Brazil

5 Departamento de Genética, Universidade Federal de Pernambuco, Recife, PE 50670-901, Brazil
Keywords Bromeliad C Cryptanthus burle-marxii . Cryptanthus zonatus $\cdot$ Microsatellite $\cdot$ Transferability

\section{Introduction}

The genus Cryptanthus Otto \& A. Dietr. (Bromeliaceae) comprises 78 species restricted to Brazil, where they occur in the Atlantic Forest, "Caatinga" and "Cerrado" (Forzza et al. 2016). These species belong to the Bromelioideae subfamily and are terrestrial and/or saxicolous herbs (Ramírez-Morillo 1996). Traditionally Cryptanthus has been recognized as sister group to the genus Orthophytum (Ramírez-Morillo 1996), but there is recent evidence that both genera are not monophyletic (Louzada et al. 2014).

Cryptanthus burle-marxii Leme and C. zonatus (Vis.) Vis. are terrestrial plants restricted to the northern portion of the Atlantic Forest in northeastern Brazil (Forzza et al. 2016). Cryptanthus burle-marxii is distributed in areas of coastal forests known as Restinga, while $C$. zonatus can be found within wet forests several kilometers from the coast. Cryptanthus zonatus also occurs in elevated islands of wet forest surrounded by "Caatinga", which are called Brejos de Altitude in Brazil (Leme and Siqueira Filho 2006). The two species are classified as threatened, specifically as Vulnerable (VU: Vulnerable category of the IUCN) by the "Livro Vermelho da Flora do Brasil" (Red List of the Brazilian Flora; Forzza et al. 2013).

These two species are considered a species complex due to overlapping morphological characters (Ramírez-Morillo 1996; Versieux et al. 2013). This complex previously included Cryptanthus fosterianus L.B. Smith before/until it was synonymized under $C$. zonatus in a recent morphological analysis (Alves and Marcucci 2015). However, a strictly morphological approach is insufficient for confident 
species delimitation in this complex. Molecular markers such as microsatellites (simple sequence repeats, SSRs) can be used in addition to morphological characters to improve confidence in taxonomy (Caddah et al. 2012). Microsatellites can be obtained by PCR (polymerase chain reaction) amplification using specific primers (Faleiro 2007). While developing custom primers for new SSRs can be cost prohibitive (Oliveira et al. 2006), it is possible to use primers previously developed for closely related species in a process called cross-amplification (Oliveira et al. 2006).

Previous studies involving the development and crossamplification of SSRs markers in Bromeliaceae have primarily focused on species of the Tillandsioideae (Boneh et al. 2003; Palma-Silva et al. 2007; Lavor et al. 2013; Neri et al. 2015) and Pitcairnioideae subfamilies (Sarthou et al. 2003; Paggi et al. 2008; Krapp et al. 2012; Miranda et al. 2012; Wöhrmann et al. 2012, 2013; Zanella et al. 2012; Hmeljevski et al. 2013). Few studies have focused on the species in the subfamily Bromelioideae (Goetze et al. 2013; Krapp et al. 2013; Aoki-Gonçalves et al. 2014). There are no published SSRs markers developed specifically for the genus Cryptanthus, only studies with crossamplification of chloroplast microsatellite markers, where primers specifically developed for Dyckia marnier-lapostollei L.B.Sm. were tested in Cryptanthus schwackeanus Mez and C. warren-loosei Leme (Krapp et al. 2013). Cross-amplification of nuclear SSRs has never been tested within the genus Cryptanthus.

Here we report the cross-amplification of nuclear microsatellite markers of Aechmea caudata Lindm. (Bromelioideae subfamily), Orthophytum ophiuroides Louzada \& Wand. (Bromelioideae), Pitcairnia albiflos Herb. (Pitcairnioideae), Vriesea gigantea (Gaud.) (Tillandsioideae) and $V$. simplex (Vell.) Beer (Tillandsioideae) in two species of the genus Cryptanthus (C. burle-marxii and C. zonatus).

\section{Materials and methods}

Sample collection and DNA extraction - We sampled fresh leaves of 38 specimens distributed in the Atlantic Forest of northeastern Brazil (states of Pernambuco and Rio Grande do Norte) (Table 1). Additionally, we stored the samples in a sodium chloride-saturated aqueous solution of $2 \%$ cetyltrimethylammonium bromide (CTAB) until DNA extraction, as described by Rogstad (1992). We collected specimens of $C$. burle-marxii (one population of 20 individuals and four specimens from selected collections in different locations) and $C$. zonatus (one population of 13 individuals and one specimen from other locality) (Table 1). We identified the specimens following the criteria of Leme and Siqueira Filho (2006). Genomic DNA was extracted from leaves following the protocol of Doyle and Doyle (1987), with modifications described by Weising et al. (2005).

Cross-amplification tests of nuclear microsatellite markers - We tested in C. burle-marxii and C. zonatus a total of 38 nuclear microsatellite markers previously developed for different Bromeliaceae species, belonging to three subfamilies (Table 2). The 38 loci tested were originally developed by Aoki-Gonçalves et al. (2014), Goetze et al. (2013), Paggi et al. (2008), Palma-Silva et al. (2007) and Neri et al. (2015).

We performed the initial cross-amplification tests using seven specimens, one individual of each population (two of C. zonatus and five of $C$. burle-marxii) (Table 1). The loci were amplified by PCR using a Veriti 96-Well Thermal Cycler (Applied Biosystems) in $12-\mu \mathrm{L}$ reactions containing: $\sim 5$ ng DNA template, $5 \times$ GoTaq Master Mix (Promega Corporation), 5 pmol forward primer, 10 pmol reverse primer, 1 pmol universal M13 primer tagged with fluorochromes (NED, FAM, VIC or PET). The forward primers contained a M13 tail with 19 base-pairs (5'CACGACGTTGTAAAACGAC- $3^{\prime}$ ) at the $5^{\prime}$ end to permit labeling with a fluorescent M13 primer during PCR amplification and genotyping.

We used the touchdown cycling program for all loci as described in detail by Palma-Silva et al. (2007). For three loci Op34, Op82 and Op87 in addition to the touchdown cycling program, we also used the standard cycling program as described in Palma-Silva et al. (2007), with the modification of an annealing temperature of $56{ }^{\circ} \mathrm{C}$. The PCR products were checked on a $1 \%$ agarose gel stained with GelRed (Biotum, Hayward, California, USA). We used the $100 \mathrm{bp}$ DNA ladder (Promega) as a molecular size marker. We considered the loci successfully amplified when at least one band of the expected size was observed.

The loci that successfully amplified were genotyped using the 3500 DNA Analyzer automated sequencer (Applied Biosystems) with a standard size GeneScan 500 LIZ (Applied Biosystems). We used the GeneMaker software, version 4.1 (Applied Biosystems) to determine the size range of alleles.

Based on the initial test of the seven individuals representing all of the populations, we choose the polymorphic loci with best pattern of genotyping to be amplified and genotyped in 33 individuals ( 20 of $C$. burle-marxii from a single population in Parque Estadual das Dunas de Natal, Voucher $=D$. Cavalcanti 757, UFP herbarium; and 13 of $C$. zonatus from a population in the RPPN Serra do Contente, Voucher $=D$. Cavalcanti 728, UFP herbarium), following the protocols described above. 
Table 1 Location of the sampled populations and number of individuals collected of Cryptanthus burle-marxii and Cryptanthus zonatus

\begin{tabular}{|c|c|c|c|c|c|c|}
\hline Species & State & Municipality & Location & Latitude S & Longitude W & $N$ \\
\hline C. burle-marxii & $\mathrm{RN}$ & Natal & Parque Estadual das Dunas de Natal & $05^{\circ} 51^{\prime} 39^{\prime \prime}$ & $35^{\circ} 11^{\prime} 05^{\prime \prime}$ & 20 \\
\hline C. burle-marxii & $\mathrm{RN}$ & Baía Formosa & RPPN Mata Estrela & $06^{\circ} 22^{\prime} 40^{\prime \prime}$ & $35^{\circ} 01^{\prime} 22^{\prime \prime}$ & 1 \\
\hline C. burle-marxii & PE & Paulista & Estação Ecológica de Caetés & $07^{\circ} 55^{\prime} 15^{\prime \prime}$ & $34^{\circ} 55^{\prime} 15^{\prime \prime}$ & 1 \\
\hline C. burle-marxii & $\mathrm{PE}$ & Ipojuca & Mata do Cupe & $08^{\circ} 26^{\prime} 58^{\prime \prime}$ & $34^{\circ} 59^{\prime} 33^{\prime \prime}$ & 1 \\
\hline C. burle-marxii & $\mathrm{PE}$ & Ipojuca & RPPN Nossa Senhora do Outeiro de Maracaípe & $08^{\circ} 31^{\prime} 48^{\prime \prime}$ & $35^{\circ} 01^{\prime} 05^{\prime \prime}$ & 1 \\
\hline C. zonatus & $\mathrm{PE}$ & Igarassu & Usina São José & $07^{\circ} 50^{\prime} 18^{\prime \prime}$ & $34^{\circ} 59^{\prime} 57^{\prime \prime}$ & . \\
\hline C. zonatus & $\mathrm{PE}$ & Gravatá & RPPN Serra do Contente & $08^{\circ} 13^{\prime} 48^{\prime \prime}$ & $35^{\circ} 35^{\prime} 10^{\prime \prime}$ & 13 \\
\hline
\end{tabular}

Rio Grande do Norte (RN), Pernambuco (PE)

\section{Data analysis}

We used the Micro-Checker program version 2.2.3 (Van Oosterhout et al. 2004) to detect the presence of null alleles per locus in the two species of Cryptanthus. The genetic diversity per locus of the two species was described by calculating: allelic richness $(A R)$, number of alleles $(A)$, observed $\left(H_{\mathrm{O}}\right)$ and expected $\left(H_{\mathrm{E}}\right)$ heterozygosity, and inbreeding coefficient $\left(F_{\text {IS }}\right)$. These calculations were done using the MSA program version 4.05 (Dieringer and Schlötterer 2003). We tested the Hardy-Weinberg equilibrium (HWE) per locus and per populations using GENEPOP, version 3.5 (Raymond and Rousset 1995).

\section{Results and discussion}

From the 38 loci tested, 24 presented successful amplification and were subsequently genotyped (Table 2). Of these, 13 were polymorphic (Table 2), and the 10 loci with best genotyping pattern were chosen for population analysis (Table 3). In the population of Cryptanthus burlemarxii, the number of alleles ranged from two to seven per locus and the allelic richness varied from 1.650 to 6.126 per locus (Table 3). The observed and expected heterozygosity ranged from 0.050 to 0.850 , and 0.050 to 0.770 per locus, respectively. In the $C$. zonatus population, the number of alleles and the allelic richness varied from two to five per locus (Table 3). The observed and expected heterozygosity ranged from 0.167 to 0.846 , and 0.290 to 0.692 per locus, respectively (Table 3 ). Therefore, the estimated values for number of alleles, allelic richness and heterozygosity per locus did not have large amplitude between the two populations of the species.

The inbreeding coefficient per locus in C. burle-marxii varied from -0.198 to 0.240 , while in the $C$. zonatus varied from -0.256 to 0.483 . The $O$. ophiuroides locus Op52 for C. zonatus and P. albiflos locus $\mathrm{PaC} 05$ for the two species showed significant departure from HWE (Table 3). The presence of null alleles was detected only for $P$. albiflos locus $\mathrm{PaC} 05$ in $C$. zonatus. The $\mathrm{PaC} 05$ significant departure from HWE in C. zonatus may have been due to the possible presence of null alleles. $C$. burle-marxii $\left(F_{\mathrm{IS}}=-0.031\right.$; $P \quad$ value $=0.840) \quad$ and $C . \quad$ zonatus $\quad\left(F_{\mathrm{IS}}=0.127\right.$; $P$ value $=0.075)$ were shown to be in Hardy-Weinberg equilibrium (HWE).

Comparing the number of alleles observed in each locus in Cryptanthus species with the species for which the loci were previously developed (Goetze et al. 2013 [A. caudata]; Aoki-Gonçalves et al. 2014 [O. ophiuroides]; Paggi et al. [P. albiflos]; and Palma-Silva et al. 2007 [V. gigantea]), it can be seen that the majority of the loci (Ac01, Op30, Op69, Op77A, Op78, VgA04) in Cryptanthus showed less alleles than those reported by the authors who had developed the loci. Only the P. albiflos locus PaC05 presented higher number of alleles (C. burle-marxii: 7 alleles and $C$. zonatus: 5 alleles) than the number reported (P. albiflos: 3 alleles) by Paggi et al. (2008).

The genetic diversity based on expected heterozygosity $\left(H_{\mathrm{E}}\right)$ in the two species ( $C$. burle-marxii and $C$. zonatus) was considered low to moderate compared with other bromeliad species which occur in forested areas, such as $V$. gigantea (Palma-Silva et al. 2009) and Bromelia antiacantha Bertoloni (Zanella et al. 2011). And it was considered more similar to that found in some bromeliads which occur on rocky outcrops, such as Alcantarea regina (Vell.) Harms (Barbará et al. 2008) and Pitcairnia staminea Lodd. (Palma-Silva et al. 2011). However, the genetic diversity in the two Cryptanthus was considered higher than found in other species which occur on rocky outcrops, such as Alcantarea geniculata (Wawra) J.R. Grant (Barbará et al. 2007), Alcantarea imperialis (Carriere) Harms (Barbará et al. 2007), Alcantarea glaziouana (Leme) J.R. Grant (Barbará et al. 2008) and P. albiflos Herb. (PalmaSilva et al. 2011).

The cross-amplification was moderate in both Cryptanthus species, about $64 \%$ of the loci tested were amplified, and about $35 \%$ of the loci tested were polymorphic. The cross-amplification in the three subfamilies tested confirms that the loci can be transferred between the different 
Table 2 Cross-amplification of 38 nuclear microsatellite markers previously developed for different Bromeliaceae species in Cryptanthus burlemarxii and Cryptanthus zonatus

\begin{tabular}{|c|c|c|c|c|}
\hline Locus & Species & Subfamily & Amplification & Polymorphic \\
\hline Ac01 & Aechmea caudata & Bromelioideae & + & + \\
\hline Ac11 & Aechmea caudata & Bromelioideae & + & - \\
\hline Ac25 & Aechmea caudata & Bromelioideae & + & - \\
\hline Ac55 & Aechmea caudata & Bromelioideae & - & \\
\hline Ac78 & Aechmea caudata & Bromelioideae & + & - \\
\hline Op08 & Orthophytum ophiuroides & Bromelioideae & - & \\
\hline Op13 & Orthophytum ophiuroides & Bromelioideae & + & - \\
\hline Op17 & Orthophytum ophiuroides & Bromelioideae & + & + \\
\hline Op18 & Orthophytum ophiuroides & Bromelioideae & - & \\
\hline Op25 & Orthophytum ophiuroides & Bromelioideae & + & + \\
\hline Op28 & Orthophytum ophiuroides & Bromelioideae & - & \\
\hline Op30 & Orthophytum ophiuroides & Bromelioideae & + & + \\
\hline Op34* & Orthophytum ophiuroides & Bromelioideae & + & $-^{\mathrm{a}}$ \\
\hline Op45 & Orthophytum ophiuroides & Bromelioideae & - & \\
\hline Op49 & Orthophytum ophiuroides & Bromelioideae & - & \\
\hline Op52 & Orthophytum ophiuroides & Bromelioideae & + & + \\
\hline Op53 & Orthophytum ophiuroides & Bromelioideae & - & \\
\hline Op63 & Orthophytum ophiuroides & Bromelioideae & - & \\
\hline Op69 & Orthophytum ophiuroides & Bromelioideae & + & + \\
\hline Op73 & Orthophytum ophiuroides & Bromelioideae & - & \\
\hline Op77A & Orthophytum ophiuroides & Bromelioideae & + & + \\
\hline Op77B & Orthophytum ophiuroides & Bromelioideae & - & \\
\hline Op78 & Orthophytum ophiuroides & Bromelioideae & + & + \\
\hline Op82* & Orthophytum ophiuroides & Bromelioideae & + & $-{ }^{\mathrm{a}}$ \\
\hline Op87* & Orthophytum ophiuroides & Bromelioideae & + & $++^{b}$ \\
\hline Op92 & Orthophytum ophiuroides & Bromelioideae & + & + \\
\hline Op93 & Orthophytum ophiuroides & Bromelioideae & + & $-{ }^{\mathrm{a}}$ \\
\hline Op95 & Orthophytum ophiuroides & Bromelioideae & + & $-{ }^{\mathrm{a}}$ \\
\hline $\mathrm{PaC} 05$ & Pitcairnia albiflos & Pitcairnioideae & + & + \\
\hline $\mathrm{PaD} 07$ & Pitcairnia albiflos & Pitcairnioideae & + & $-{ }^{\mathrm{a}}$ \\
\hline PaZ01 & Pitcairnia albiflos & Pitcairnioideae & - & \\
\hline VgA04 & Vriesea gigantea & Tillandsioideae & + & + \\
\hline $\mathrm{VgC01}$ & Vriesea gigantea & Tillandsioideae & + & + \\
\hline VgF02 & Vriesea gigantea & Tillandsioideae & - & \\
\hline Vs1 & Vriesea simplex & Tillandsioideae & + & $-{ }^{\mathrm{a}}$ \\
\hline Vs8 & Vriesea simplex & Tillandsioideae & + & $-{ }^{\mathrm{a}}$ \\
\hline Vs9 & Vriesea simplex & Tillandsioideae & - & \\
\hline Vs10 & Vriesea simplex & Tillandsioideae & - & \\
\hline
\end{tabular}

${ }^{a}$ Pattern of genotyping unanalyzable

b Pattern of genotyping unanalyzable with touchdown cycling program and polymorphic with standard cycling program

* Touchdown cycling program and standard cycling program were used; species from different subfamilies of Bromeliaceae (Palma-Silva et al. 2007; Paggi et al. 2008; Krapp et al. 2012; Zanella et al. 2012; Goetze et al. 2013; Lavor et al. 2013; Aoki-Gonçalves et al. 2014; Neri et al. 2015).
The ten polymorphic loci transferred to Cryptanthus burle-marxii, and $C$. zonatus will be used to assess the genetic diversity and structure of natural populations of these species. Such studies are expected to give insights 
Table 3 Genetic diversity parameters estimated for ten polymorphic nuclear microsatellite loci transferred to Cryptanthus burle-marxii and Cryptanthus zonatus

\begin{tabular}{|c|c|c|c|c|c|c|c|c|c|c|c|c|}
\hline \multirow[t]{2}{*}{ Locus } & \multicolumn{6}{|c|}{ Cryptanthus burle-marxii $(n=20)$} & \multicolumn{6}{|c|}{ Cryptanthus zonatus $(n=13)$} \\
\hline & Size range (bp) & $A$ & $A R$ & $H_{\mathrm{O}}$ & $H_{\mathrm{E}}$ & $F_{\text {IS }}$ & Size range (bp) & $A$ & $A R$ & $H_{\mathrm{O}}$ & $H_{\mathrm{E}}$ & $F_{\text {IS }}$ \\
\hline Ac01 & $283-285$ & 2 & 1.883 & 0.100 & 0.097 & -0.040 & $285-287$ & 2 & 2 & 0.385 & 0.409 & 0.042 \\
\hline Op17 & $173-177$ & 3 & 2.993 & 0.450 & 0.476 & 0.042 & $173-175$ & 2 & 2 & 0.167 & 0.290 & 0.418 \\
\hline Op25 & $171-175$ & 3 & 2.993 & 0.450 & 0.476 & 0.042 & $171-173$ & 2 & 2 & 0.167 & 0.290 & 0.418 \\
\hline Op30 & $132-138$ & 3 & 3 & 0.778 & 0.660 & -0.198 & $132-140$ & 3 & 3 & 0.846 & 0.692 & -0.253 \\
\hline Op52 & $265-267$ & 2 & 1.836 & 0.200 & 0.185 & -0.099 & $245-273$ & 3 & 3 & 0.714 & 0.648 & $-0.150 *$ \\
\hline Op69 & $114-134$ & 7 & 5.449 & 0.850 & 0.728 & -0.185 & $122-132$ & 4 & 4 & 0.818 & 0.671 & -0.256 \\
\hline Op77A & $159-161$ & 2 & 1.650 & 0.050 & 0.050 & -0.013 & $159-161$ & 2 & 2 & 0.462 & 0.443 & -0.064 \\
\hline Op78 & $221-233$ & 5 & 4.960 & 0.750 & 0.756 & -0.004 & $227-233$ & 3 & 3 & 0.462 & 0.588 & 0.202 \\
\hline $\mathrm{PaC05}$ & $185-207$ & 7 & 6.126 & 0.579 & 0.770 & $0.240 *$ & $165-195$ & 5 & 5 & 0.333 & 0.652 & $0.483 *$ \\
\hline VgA04 & $175-177$ & 2 & 1.989 & 0.200 & 0.185 & -0.099 & $175-177$ & 2 & 2 & 0.231 & 0.409 & 0.430 \\
\hline
\end{tabular}

Number of alleles $(A)$, allelic richness $(A R)$, observed heterozygosity $\left(H_{\mathrm{O}}\right)$, expected heterozygosity $\left(H_{\mathrm{E}}\right)$, inbreeding coefficient $\left(F_{\mathrm{IS}}\right)$

* Significant departure from HWE $(P<0.05)$

into the evolutionary history and processes involved in their divergence. With the data genetic structure, we will analyze if it is occurring interspecific gene flow between $C$. burle-marxii and $C$. zonatus and test the hypothesis that they are, in fact, the same species.

Acknowledgements This paper is part of the first author's Master thesis conducted in the Programa de Pós-Graduação em Biologia Vegetal (PPGBV) from Universidade Federal de Pernambuco (UFPE). The first author thanks the Coordenação de Aperfeiçoamento de Pessoal de Nível Superior (CAPES) for her M.Sc. scholarship and the Fundação de Amparo à Ciência e Tecnologia do Estado de Pernambuco (FACEPE). The authors thank the Projeto Universal, funded by Conselho Nacional de Desenvolvimento Científico e Tecnológico (CNPq) (449686/2014-0) and the Atlantic Forest Project, funded by CNPq, NSF (DEB-0946618), Velux Stiftung and Beneficia Foundation. The authors also thank the CEIS Laboratory of the Universidade Estadual Paulista Júlio de Mesquita Filho (UNESP)—Rio Claro, for sample genotyping.

\section{References}

Alves M, Marcucci R (2015) Nomenclatural correction in Cryptanthus Otto \& A. Dietrich. (Bromeliaceae-Bromelioideae). Rodriguésia 66:661-664. doi:10.1590/2175-7860201566229

Aoki-Gonçalves F, Louzada RB, Souza LM, Palma-Silva C (2014) Microsatellite Loci for Orthophytum ophiuroides (Bromelioideae, Bromeliaceae) species adapted to neotropical rock outcrops. Appl Plant Sci 2:1-4. doi:10.3732/apps.1300073

Barbará T, Martinelli G, Fay MF, Mayo SJ, Lexer C (2007) Population differentiation and species cohesion in two closely related plants adapted to Neotropical high-altitude 'inselbergs', Alcantarea imperialis and A. geniculata. Mol Ecol Resour 16:1981-1992. doi:10.1111/j.1365-294X.2007.03272.x

Barbará T, Lexer C, Martinelli G, Mayo S, Fay MF, Heuertz M (2008) Within-population spatial genetic structure in four naturally fragmented species of a neotropical inselberg radiation, Alcantarea imperialis, A. geniculata, A. glaziouana and A. regina (Bromeliaceae). Heredity 101:285-296. doi:10.1038/hdy. 2008.65

Boneh L, Kuperus P, Tienderen HV (2003) Microsatellites in the bromeliads Tillandsia fasciculata and Guzmania monostachya. Mol Ecol Notes 3:302-303. doi:10.1046/j.1471-8286.2003. 00432.x

Caddah MK, Mayer JLS, Bittrich V, Amaral MCE (2012) Species limits in the Kielmeyera coriacea complex (Calophyllaceae) - a multidisciplinary approach. Bot J Linn Soc 168:101-115. doi:10. 1111/j.1095-8339.2011.01192.x

Dieringer D, Schlötterer C (2003) Microsatellite analyser (MSA): a platform independent analysis tool for large microsatellite data sets. Mol Ecol Notes 3:167-169. doi:10.1046/j.1471-8286.2003. 00351.x

Doyle JA, Doyle JL (1987) A rapid DNA isolation procedure for small quantities of fresh leaf 526 tissue. Phytochem Bull 19:11-15

Faleiro FG (2007) Marcadores Genético-Moleculares aplicados a programas de conservação e uso de recursos genéticos. Embrapa, Planaltina

Forzza RC, Costa AF, Leme EMC, Versieux LM, Wanderley MGL, Louzada RB, Monteiro RF, Judice DM, Fernandez EP, Borges RAX, Penedo TSA, Monteiro NP, Moraes MA (2013) Bromeliaceae. In: Martinelli G, Moraes MA (eds) Livro Vermelho da Flora do Brasil. Andrea Jakobsson, Instituto de Pesquisas Jardim Botânico do Rio de Janeiro, Rio de Janeiro, pp 315-396

Forzza RC, Costa A, Siqueira Filho JA, Martinelli G, Monteiro RF, Santos-Silva F, Saraiva DP, Paixão-Souza B, Louzada RB, Versieux L (2016) Bromeliaceae. In: Lista de Espécies da Flora do Brasil. Jardim Botânico do Rio de Janeiro. http://floradobra sil.jbrj.gov.br/jabot/floradobrasil/FB5991. Accessed 10 Nov 2015

Goetze M, Louzada RB, Wanderley MGL, Souza LM, Bered F, Palma-Silva C (2013) Development of microsatellite markers for genetic diversity analysis of Aechmea caudata (Bromeliaceae) and cross-species amplification in other bromeliads. Biochem Syst Ecol 48:194-198. doi:10.1016/j.bse.2012.12.022

Hmeljevski KV, Ciampi MB, Baldauf C, Reis MS, Forzza RC (2013) Development of SSR Markers for Encholirium horridum (Bromeliaceae) and Transferability to Other Pitcairnioideae. Appl Plant Sci 1:1-4. doi:10.3732/apps.1200445 
Krapp F, Wöhrmann T, Pinangé DSB, Benko-Iseppon AM, Huettel B, Weising K (2012) A set of plastid microsatellite loci for the genus Dyckia (Bromeliaceae) derived from 454 pyrosequencing. Am J Bot 99:470-473. doi:10.3732/ajb.1200153

Krapp F, Cruz GAS, Wöhrmann T, Benko-Iseppon AM, Weising K (2013) A set of variable plastid SSR markers for the genus Cryptanthus (Bromeliaceae). Res Plant Biol 3:18-21

Lavor P, van den Berg C, Versieux LM (2013) Transferability of 10 nuclear microsatellite primers to Vriesea minarum (Bromeliaceae), a narrowly endemic and threatened species from Brazil. Braz J Bot 36:165-168. doi:10.1007/s40415-013-0012-7

Leme EMC, Siqueira Filho JA (2006) Taxonomia das bromélias dos fragmentos de mata atlântica de Pernambuco e Alagoas. In: Siqueira Filho JA, Leme EMC (eds) Fragmentos de mata atlântica do Nordeste-biodiversidade, conservação e suas bromélias. Andrea Jakobsson Estúdio, Rio de Janeiro, pp 190-381

Louzada RB, Schulte K, Wanderley MGL, Silvestro D, Zizka G, Barfuss MHJ, Palma-Silva C (2014) Molecular phylogeny of the Brazilian endemic genus Orthophytum (Bromelioideae, Bromeliaceae) and its implications on morphological character evolution. Mol Phylogenet Evol 77:54-64. doi:10.1016/j.ympev.2014. 03.007

Miranda FD, Gontijo ABPL, Santiliano FC, Favoreto FC, Soares TCB (2012) Transferability and characterization of microsatellite markers in five Bromeliaceae species belonging to the subfamilies Pitcairnoideae and Bromelioideae. Biota Neotrop 12:319-323

Neri J, Nazareno AG, Wendt T, Palma-Silva C (2015) Development and characterization of microsatellite markers for Vriesea simplex (Bromeliaceae) and cross-amplification in other species of Bromeliaceae. Biochem Syst Ecol 58:34-37. doi:10.1016/j. bse.2014.10.004

Oliveira EJ, Pádua JG, Zucchi MI, Vencovsky R, Vieira MLC (2006) Origin, evolution and genome distribution of microsatellites. Genet Mol Biol 29:294-307. doi:10.1590/S141547572006000200018

Paggi GM, Palma-Silva C, Bered F, Cidade FW, Sousa ACB, Souza AP, Wendt T, Lexer C (2008) Isolation and characterization of microsatellite loci in Pitcairnia albiflos (Bromeliaceae), an endemic bromeliad from the Atlantic Rainforest, and crossamplification in other species. Mol Ecol Resour 8:980-982. doi:10.1111/j.1755-0998.2008.02126.x

Palma-Silva C, Cavallari MM, Barbará T, Lexer C, Gimenes MA, Bered F, Bodanese-Zanettini MH (2007) A set of polymorphic microsatellite loci for Vriesea gigantea and Alcantarea imperialis (Bromeliaceae) and cross-amplification in other bromeliad species. Mol Ecol Notes 7:654-657. doi:10.1111/j.1471-8286. 2006.01665.x

Palma-Silva C, Lexer C, Paggi GM, Barbará T, Bered F, BodaneseZanettini MH (2009) Range-wide patterns of nuclear and chloroplast DNA diversity in Vriesea gigantea (Bromeliaceae), a neotropical forest species. Heredity 103:503-512. doi:10.1038/ hdy. 2009.116

Palma-Silva C, Wendt T, Pinheiro F, Barbará T, Fay MF, Cozzolino S, Lexer C (2011) Sympatric bromeliad species (Pitcairnia spp.) facilitate tests of mechanisms involved in species cohesion and reproductive isolation in Neotropical inselbergs. Mol Ecol Resour 20:3185-3201. doi:10.1111/j.1365-294X.2011.05143.x

Ramírez-Morillo IM (1996) Systematics, phylogeny, and chromosome number evolution of Cryptanthus (Bromeliaceae). Ph.D. dissertation, University of Missouri, St. Louis

Raymond M, Rousset F (1995) GENEPOP (Version 1.2): population Genetics Software for Exact Tests and Ecumenicism. J Hered $86: 248-249$

Rogstad SH (1992) Saturated NaCI-CTAB solution as a means of field preservation of leaves for DNA analyses. Taxon 41:701-708

Sarthou C, Boisselier-Dubayle MC, Lambourdière J, Samadi S (2003) Polymorphic microsatellites for the study of fragmented populations of Pitcairnia geyskesii L. B. Smith (Bromeliaceae), a specific saxicolous species of inselbergs in French Guiana. Mol Ecol Notes 3:221-223. doi:10.1046/j.1471-8286.2003.00404.x

Van Oosterhout C, Hutchinson WF, Wills DPM, Shipley P (2004) MICRO-CHECKER: software for identifying and correcting genotyping errors in microsatellite data. Mol Ecol Notes 4:535-538. doi:10.1111/j.1471-8286.2004.00684.x

Versieux LM, Magalhães R, Calvente A (2013) Extension of the Cryptanthus range in Northeastern Brazil with new findings in the phenotypic variation including changes in the trichome's distribution, thus enhancing the understanding of the Cryptanthus zonatus complex (Bromeliaceae). Phytotaxa 109:54-60. doi:10.11646/phytotaxa.109.1.6

Weising K, Nybom H, Wolff K, Kahl G (2005) DNA fingerprinting in plants: principles, methods, and applications, 2nd edn. CRC Press, Boca Raton

Wöhrmann T, Wagner N, Krapp F, Huettel B, Weising K (2012) Development of microsatellite markers in Fosterella rusbyi (Bromeliaceae) using 454 pyrosequencing. Am J Bot. doi:10. 3732/ajb.1100470

Wöhrmann T, Pinangé DSB, Krapp F, Benko-Iseppon AM, Huettel B, Weising K (2013) Development of 15 nuclear microsatellite markers in the genus Dyckia (Pitcairnioideae; Bromeliaceae) using 454 pyrosequencing. Conserv Genet Resour 5:81-84. doi:10.1007/s12686-012-9738-y

Zanella CM, Bruxel M, Paggi GM, Goetze M, Buttow MV, Cidade FW, Bered F (2011) Genetic structure and phenotypic variation in wild populations of the medicinal tetraploid species Bromelia antiacantha (Bromeliaceae). Am J Bot 98:1511-1519. doi:10. 3732/ajb. 1000458

Zanella CM, Janke A, Paggi GM, Goetze M, Reis MS, Bered F (2012) Microsatellites in the endangered species Dyckia distachya (Bromeliaceae) and cross-amplification in other bromeliads. Int $\mathrm{J}$ Mol Sci 13:15859-15866. doi:10.3390/ijms131215859 